\title{
血管睡・血管奇形に対する interventional radiology
}

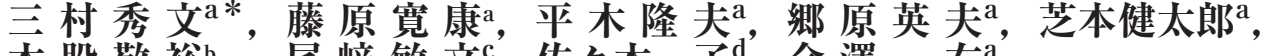

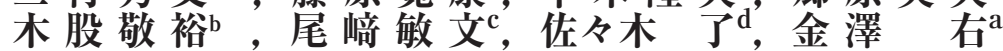 \\ 岡山大学大学院医歯薬学総合研究科 a放射線医学, b形成再建外科学, c整形外科学,
}

d斗南病院形成外科

キーワード：血管奇形，静眽奇形，動静脈奇形，塞栓術，硬化療法

\section{Interventional radiology for vascular anomalies}

Hidefumi Mimura $^{\mathrm{a} *}$, Hiroyasu Fujiwara ${ }^{\mathrm{a}}$, Takao Hiraki ${ }^{\mathrm{a}}$, Hideo Gobara ${ }^{\mathrm{a}}$, Kentaro Shibamoto ${ }^{\mathrm{a}}$, Yoshihiro Kimata $^{\mathrm{b}}$, Toshifumi Ozaki ${ }^{\mathrm{c}}$, Satoru Sasaki ${ }^{\mathrm{d}}$, Susumu Kanazawa ${ }^{\mathrm{a}}$

Departments of aRadiology, bPlastic and Reconstructive Surgery, ${ }^{c}$ Orthopedic Surgery, Okayama University Graduate School of Medicine,

Dentistry and Pharmaceutical Sciences, ${ }^{\mathrm{d} D e p a r t m e n t ~ o f ~ P l a s t i c ~ a n d ~ R e c o n s t r u c t i v e ~ S u r g e r y, ~ T o n a n ~ H o s p i t a l ~}$

\section{はじめに}

表在性の血管腫・血管奇形 (vascular anomalies) は まれな疾患で, その発生部部位により種々の診療科に より診療されており, 疾患概念と治療法について臨床 医の間で混乱がみられる。血管腫と血管奇形は異なる 疾患であり, 治療法が異なる. 頻度の高い乳児血管腫 は生後急速に増大し，幼児期に徐々に退縮する病変で あり, 通常治療を要さない。血管奇形は疼痛・潰瘍・ 出血・感染などを来たしてしばしば治療を要する。従 来保存的治療 - 外科的切除が行われてきたが, 近年機 能・形態の温存が可能な Interventional Radiology (IVR), すなわち硬化療法・塞栓術が新しい治療とし て普及してきており，国際的に標準治療となりつつあ る。しかしながらこれらは本邦においては保険適応で すらない。血管奇形には巨大で一肢全体に及ぶなど切 除不能病変・難治性病変が少なくない。患者は幼少時 より病変による症状に苦しみ, 治療法がないと言われ， 多くの診療科を渡り歩き, 治療難民とも言える状態に ある. 2009年夏, 厚生労働省難治性疾患克服研究事業 として,「難治性血管腫・血管奇形に対する調査研究 班」(研究代表者佐々木了：斗南病院形成外科）が発足 した。研究分野には形成外科学・放射線医学・病理 学・疫学・分子生物学などの基礎医学が含まれる. 研

平成 22 年 1 月受理

* 7 700-8558 岡山市北区鹿田町 2-5-1

電話：086-235-7313 FAX：086-235-7316

E-mail : hmimura@cc.okayama-u.ac.jp
究班発足の背景として，患者団体「混合性血管奇形を 難病指定にする会」，「血管腫・血管奇形患者会」の発 足，厚生労働省への働きかけがあり，彼らは多くの困 っている患者の中の水山の一角に過ぎない。本稿では 血管腫・血管奇形の疾患概念, 先端治療としてのIVR, 「難治性血管腫・血管奇形に対する調査研究班」の取 り組みについて述べる。

\section{Vascular anomalies の分類}

1982年，Mulliken と Glowacki が病理組織所見に基 づいて血管病変を血管性腫瘍（血管腫など）と血管奇 形の二つに区別した。この分類の基本的な考え方は， 血管腫は内皮細胞の腫瘍性増殖によって生じる病変で あり，血管奇形は形成異常により生じる病変で内皮細 胞の turnover は正常である, とするものであり, 明確 である。近年この分類を基に考案された The International Society for the Study of Vascular Anomalies （ISSVA）の提唱している分類（ISSAVA 分類）（表 $1)^{1)}$ に基づいて診断を行い，治療方針を決定すること が国際的に標準化しつつある. ISSVA 分類の利点は, なるべく単純でわかりやすい世界共通の病名を用いて 血管腫と血管奇形を区別することにより適切な臨床診 断と治療方針を導くことにある。しかし，日本ではこ のような血管腫・血管奇形の疾患概念・分類方法がほ とんど知られていない.

乳児血管腫（infantile hemangioma）

乳児血管腫は乳児期に最も多い腫瘍で，血管内皮細 胞の腫瘍性増殖とアポトーシスによる退縮をきたす。 
生後 $1 \sim 4$ 週に出現し, 1 年以内に急速に増大する(増 殖期). その後 $90 \%$ 以上の血管腫は $5 \sim 7$ 歳までに数年 かけて徐々に自然消退する (退縮期). $3 ： 1$ の頻度で 女性に多い, 局面型, 腫瘤型, 皮下型があり, 皮下型 では静脈奇形と混同されることが多い. 乳児血管腫で は増殖期, 退縮期を通じて erythrocyte-type glucose transporter（GLUT1）免疫染色が陽性となるのに対 し，血管奇形では陰性となる。

多くの血管腫は自然消退するため, 経過観察のみで 特に治療を必要としないが, 整容目的でレーザー治療 や切除が行われることもある. 重要臓器の圧迫, 機能 低下, 気道閉塞を生じる可能性がある病変に対しては, ステロイドの全身投与あるいは局注, インターフェロ ンの投与, 塞栓術, 外科手術などが施行される.

\section{血管奇形 (vascular malformation)}

血管奇形は発生学的には胎生 $4 \sim 10$ 週の末梢血管系 形成期の異常によって生じ，その構成成分によって， 毛細血管奇形, 静脈奇形, リンパ管奇形, および動静 脈奇形等に分類される $(\text { 表 } 1)^{1)}$. 発生頻度に性差はな く, 成長期などにゆっくりと増大し, 退縮しない。

\section{1 ）静脈奇形（venous malformation）}

静脈奇形は筋層外皮の低形成をきたした拡張した静 脈腔で構成される. 従来海綿状血管腫, 筋肉内血管腫 と呼ばれてきた病変は静脈奇形である。周囲組織の圧 迫, 血栓形成による疼痛や機能障害を生じることがあ る.

静脈奇形の保存的治療には, 疼痛や腫脹に対して弾 性衣類による圧迫が用いられる. 疼痛・出血・機能障 害を有するか経過観察で急速に増大する病変に対し て, あるいは整容目的で, 従来手術が行われてきたが, 近年硬化療法が手術に取って代わる治療になりつつあ

表 1 ISSVA Classification of Vascular Anomalies* 参考文献 1）より引用

\begin{tabular}{ll}
\hline Tumors & Malformations \\
Hemangioma & simple \\
Other & capillary (C) \\
& lymphatic (L) \\
& venous (V) \\
& combined \\
& AVF, AVM, CVM, CLVM, LVM, \\
& CAVM, CLAVM \\
\hline
\end{tabular}

*ISSVA $=$ The International Society for the Study of Vascular Anomalies.
る.

\section{2 ）動静脈奇形（arteriovenous malformation)}

動静脈奇形は動脈と静脈が正常の毛細血管床を介さ ずに，異常な交通を生じた先天性の病変である。動静 脈奇形の臨床症状を Schöbinger 分類（表 2$)^{2}$ )で示す. 動静脈奇形の保存的治療として, 四肢病変では, 静 脈圧上昇による疼痛や腫脹に対して, 弾性衣類による 圧迫が用いられる。動静脈奇形の塞栓術や手術は難し く, 確立された適応・方法があるわけではない。一般 にSchöbinger 分類第 II 期までで症状が軽く, 日常生活 に支障がないかぎりは経過観察とし，症状が増悪した 場合に積極的な治療を考慮する。しかしながら，潰瘍 が形成されると治療が困難になるため, 腫脹した段階 で塞栓術あるいは手術を行うという意見もある。 Schöbinger 分類第血期以降で, 病変が筋肉・骨など深 部に及んだり，広範囲に進展する場合，あるいは手術 後の再発例は塞栓術の良い適応となる。

\section{3 ) 毛細血管奇形 (capillary malformation)}

皮膚の毛細血管拡張による赤色から暗赤色の色素斑 であり, 顔面・体幹部に好発する。単純性血管腫, portwine stain と呼ばれてきた病変である，整容目的の治 療が主となり，積極的治療としてはレーザー治療・切 除が行われる，血管内治療の適応とはならない。

\section{4 ）リンパ管奇形 (lymphatic malformation)}

リンパ管の形成不全であり, 胎生期の未熟リンパ組 織がリンパ管に接合できずに，孤立してのう腫状に拡 張した病変と考えられている。リンパ管腫と呼ばれて きた病変である.Microcystic(従来の lymphangioma), macrocystic（従来の cystic hygroma）に分類される. しばしば炎症を伴い, 一時的に増大し, 腫脹・発赤・ 熱感・疼痛を来たす。保存的治療としては炎症を来た した際に抗生剂, 抗炎症剂が投与される。積極的治療 としては硬化療法・切除が行われる。硬化療法は macrocystic type に有効であるが, microcystic type で は無効のことが多いと言われている.

\section{表 2 Schöbinger's classification}

参考文献 2）より引用

\begin{tabular}{lll}
\hline Stage & Features \\
\hline I & 静止期 & 皮膚紅潮, 温感 \\
II & 拡張期 & 血管雑音, 拍動音の聴取, 増大 \\
III & 破壊期 & 疼痛, 潰瘍, 出血, 感染 \\
IV & 代償不全期 & 心不全 \\
\hline
\end{tabular}




\section{血管奇形に対する Interventional Radiology（IVR）： 硬化療法・塞栓術の実際}

静脈奇形には直接穿刺の硬化剂注入による硬化療 法, 動静脈奇形には経動脈的・直接穿刺・経静脈的塞 栓物質注入による塞栓術が施行される. 硬化療法と塞 栓術の厳密な区別があるわけではなく，血管を閉塞さ せるという意味では結果は同じである。

\section{静脈奇形の硬化療法}

欧米では広く施行されているが，日本では健康保険 で認可されていない事情もあり，限られた施設で施行 されている. 静脈奇形内の拡張した静脈腔が標的であ り，直接穿刺により硬化郕を注入する。

硬化剂としては日本では 3 種類の硬化剂が入手可能 で, エタノール, エタノラミンオレエイト, ポリドカ ノールが使用されている. 我々は現在四肢静脈奇形に 対しては主にポリドカノールフォームを第一選択とし て使用している。ポリドカノールフォームは 2 つのシ リンジ内の $3 \%$ \%゚リ゙カノール $1 \mathrm{ml} と \mathrm{CO}_{2} 4 \mathrm{ml} 三$ 方 活栓でつないで10往復することにより混和して作成す る。使用可能な硬化剤の量を増やし, 硬化㓮の血管壁 への接着性を増し, 血管攣縮を引き起こし, 効果を増 強させることができる。

術中の疼痛対策として一般的にポリドカノール，エ タノラミンオレイトを使用する場合は局所麻酔, エ夕 ノールを使用する場合は全身麻酔あるいは腰椎麻酔な どを選択する，超音波ガイド下あるいは触診を基に静
脈奇形内に直接針を穿刺し，血液の逆流を確認して造 影を施行する．静脈奇形内に造影剂がたまらずに静脈 に流出する場合は，駆血するかあるいは流出静脈が表 在性であれば用手などで圧迫し，血流を停滞させる。 透視で観察しながら硬化剂を注入する。通常数か所穿 刺し，硬化剂を注入する（図 1 ).

エタノール硬化療法の成績は症状の改善あるいは病 変の縮小を有効とすると 64 ～96\%で有効であった ${ }^{3)}$. 合併症は7.5 27.9\%でみられ, 皮膚水泡, 皮膚壊死, 一時的な疼痛, 筋拘縮, 運動・知覚神経障害, 表層蜂 窩織炎, 深部静脈血栓症, 肺塞栓症, 心肺虚脱などで ある3 ${ }^{3)}$ Cabrera らによるとポリドカノールフォーム硬 化療法は50例中46例（92\%）で有効であり，重篤な合 併症はなく, 皮膚の色素沈着が 4 例, 皮膚壊死が 3 例 でみられた，と報告している4)。我々はポリドカノー ル液体を用いた硬化療法を施行し，90\%で疼痛改善効 果があり, $10 \mathrm{~cm}$ 以下の小さい病変, 境界明瞭な病変, 硬化㓮の停滞が良好な病変でより効果が高かったと報 告した5)。

\section{動静脈奇形の塞栓術}

動静脈奇形は流入動脈・ nidus・流出動脈により構 成されるが，このうち毛細血管を介さない動・静脈の 異常吻合の集合体が nidus であり，塞栓術における真 の標的である. 経動脈的, 直接穿刺, 経静脈的塞栓術 を単独あるいは組み合わせて施行する。

液体塞栓物質は本症の塞栓術に最も有用な塞栓物質 で, n-butyl-2-cyanoacrylate：NBCA（ヒストアクリ

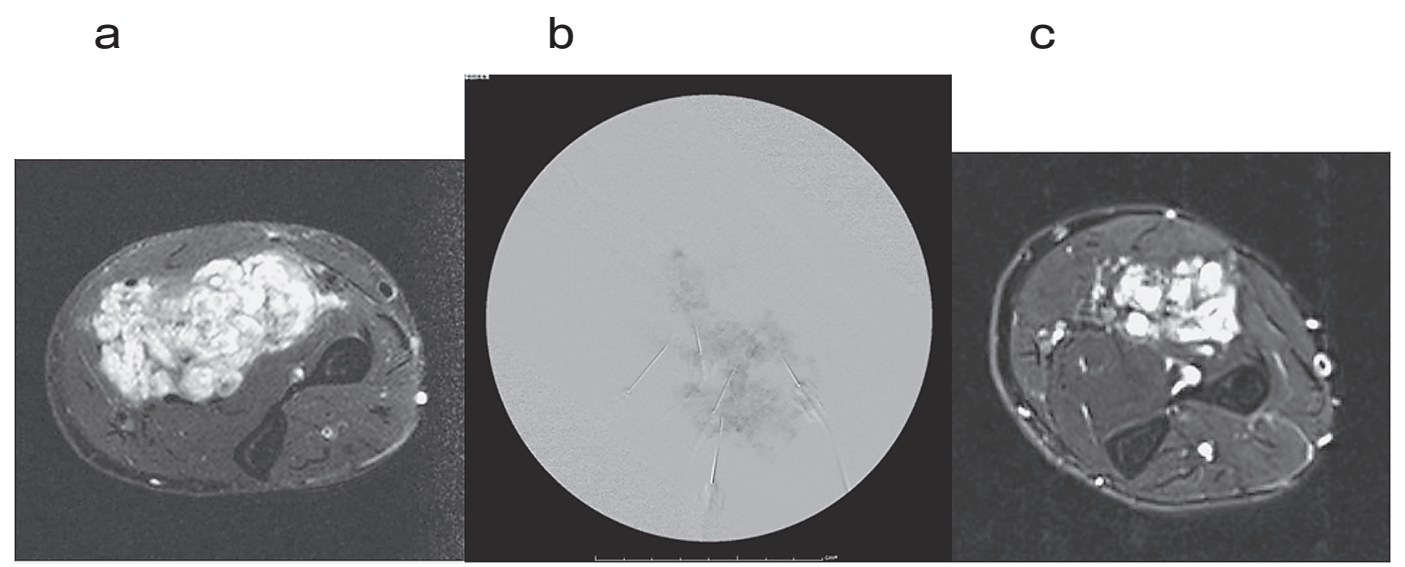

図 1 前腕静脈奇形。59歳女性, 主訴は疼痛.

a）硬化療法前 MRI 脂肪抑制 T 2 強調像. 静脈奇形は主に筋肉内にあり, 著明な高信号を呈している，b）硬化療法中の DSA（digital subtraction angiography)。経皮的に細径針を直接穿刺し，造影剤と混和した硬化剂（ポリドカノール）を注入している。c）硬化療 法後 3 年 MRI 脂肪抑制 T 2 強調像. 静脈奇形は縮小している. 疼痛は消失している. 
ル）・リピオドール混和液や，エタノールが用いられ る. 接着剤材料である NBCA はリピオドール（油性造 影剤）と混和して重合時間の調節，透視下での視認が 可能となる. エ夕ノールは血漿蛋白の変性作用や破壊 的な血管内皮障害による即時的な血栓形成をもたら し, 根治的に近い効果が期待できる. 粒状塞栓物質は 国内では市販されていないが, polyvinyl alcohol (PVA), SAP-microsphere, Embosphere, Embozene などの永久塞栓物質がある。これらは粒子径により, 規格が分けられており, nidusを通過しない粒子を選 択することが可能である。

多くの施設で液体塞栓物質が使用され, NBCA も工 タノールも注入時に激烈な疼痛があるため, 術中の疼 痛対策として通常全身麻酔（あるいは腰椎麻酔など） を選択する，粒状塞栓物質のみを使用する場合は局所 麻酔のみで施行可能である. 経動脈的にはマイクロカ テーテルをできるだけ nidusまで進め, 塞栓物質を注 入し, nidus を塞栓する. Nidusの直接穿刺による硬化 剤の注入は硬化療法と類似した手技である。Nidusを 閉塞させ，短絡を消失させることが治療目標である。 病変の近位動脈の塞栓のみでは短絡が残存して治療効 果が得られず，虚血による刺激のため病変が増大する 危険性があり，さらに追加治療を困難にさせるため望 ましくない.

Cho らは動静脈奇形66例に対し,255セッションのエ タノール塞栓術を施行し，49例（74\%）で奏功し， 21 例で根治，28例で部分寛解が得られたと報告してい $ろ^{6)}$. 合併症として, 水疮, 皮膚壊死, 神経障害, 感 染症，遠位塞栓，膀胱壊死，脳梗塞，腎不全がみられ た。また, 彼らは動静脈奇形をその形態から type I (arteriovenous fistulae), type II (arteriolovenous fistulae), type III a (arteriolovenulous fistulae with non-dilated fistula), type $\mathrm{II} b$ (arteriolovenulous fistulae with dilated fistula) に分類し（図 2 ), Type II では直接穿刺と経静脈的塞栓術, type III a では経動 脈的塞栓術, type IIIbでは経動脈的と直接穿刺塞栓術 が主たる適応となると述べている。さらにエタノール 塞栓術の奏功率は type II で100\%, type IIIb で83\%, type III $\mathrm{a}$ や混合型では50\%以下であったと述べている.

\section{「難治性血管腫・血管奇形に対する調査研究班」の発 足について}

\section{研究の概要}

既述のとおり，2009年夏，厚生労働省難治性疾患克 服研究事業として,「難治性血管腫・血管奇形に対する 調査研究班」が発足した。本研究は血管腫・血管奇形 の症例登録を多施設からなる組織によって推進し，国 内の患者数を可及的に把握し，病因に基づく分類と疾 患概念の形成を目指す。さらに，患部組織の病理学的 解析, トランスクリプトーム解析, 血管病変の分子生 物学的解析等の基礎研究を推進することで, 生物学的 事実に基づく血管腫・血管奇形の分類，および治療指

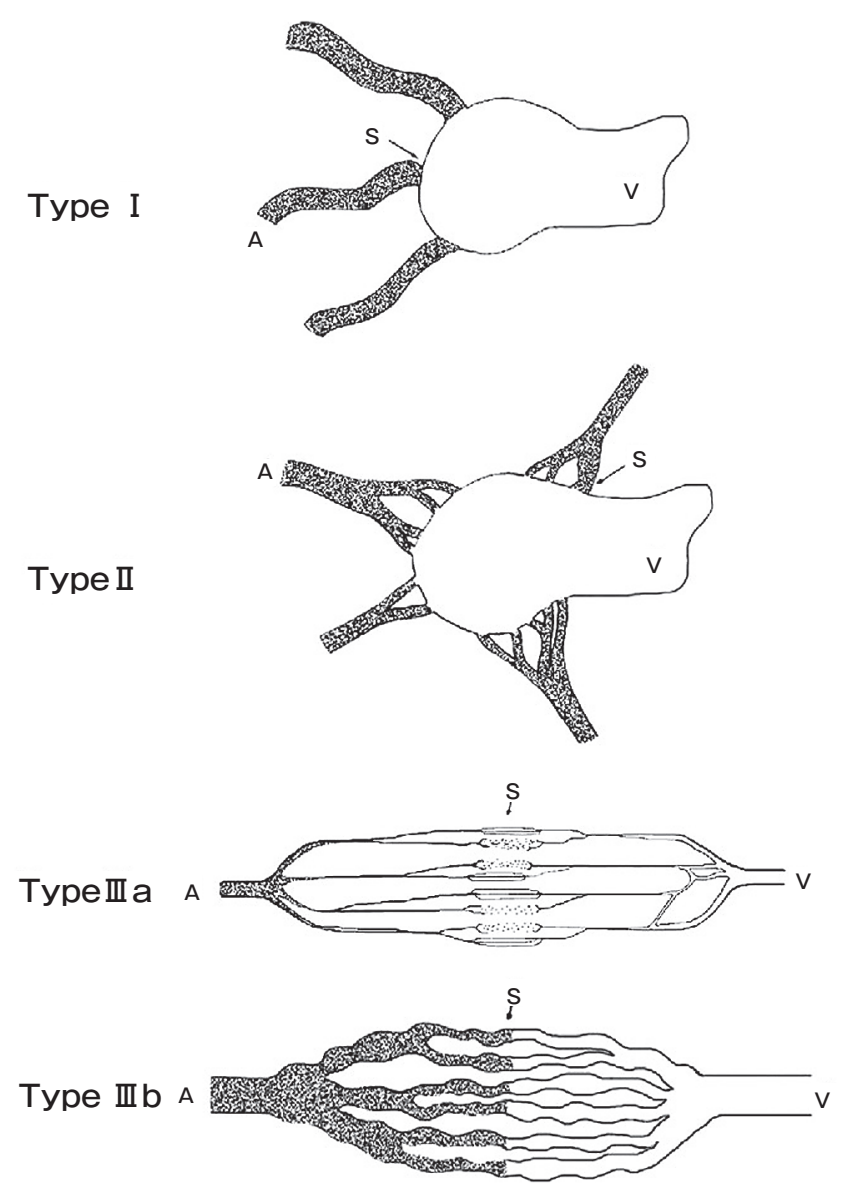

図 2 血管造影によるAVM の分類（参考文献 6 ）より引用） Type I (arteriovenous fistulae)：3 本以下の動脈が 1 本の静 脈に短絡している. Type II (arteriolovenous fistulae) : 多数の 細動脈が 1 本の静脈に短絡している. Type III a (arteriolovenulous fistulae with non-dilated fistula) : 多数の細動脈と多数の 細静脈との間に細い多数の短絡がある. Type IIIb (arteriolovenulous fistulae with dilated fistula): 多数の細動脈と多数の 細静脈との間に拡張した多数の短絡がある. A : 㾇の動脈成分, $\mathrm{V}$ : 瘻の静脈成分, $\mathrm{S}$ : 短絡 
針・客観的な診断基準の作成をめざす.世界的研究実 情の把握, 疫学デー夕の収集, 協力施設の患者登録体 制の構築, 生検標本の病理・分子生物学的解析, 診断 基準及び治療ガイドライン素案の作成を行う. ヒト材 料を用いた研究は各施設の倫理委員会の承認のもと行 われる。

\section{研究方法}

本研究は 3 カ年計画であり, 以下の 3 項目を重点化 し調査・研究を行う.

(1)疾患概念の形成と患者実態の把握

- 協力施設からの症例登録協力体制の構築と一元化登 録管理

- ISSVA分類基準に基づく登録患者の分類と分析

・血管腫・血管奇形疾患の啓蒙のための疾患情報ホー ムページの作成

・診断基準, 治療ガイドライン素案の作成

・患者聞き取り（アンケート）調査によるQOLスコア 化の調査

・病理・遺伝子学的情報を加味した治療指針の作成

(2)血管病変の病理学的解析

- 血管腫・血管奇形症例標本を用いた病理学的分類と レトロスペクティブ解析

・血管腫・血管奇形マーカーの探索

(3)血管病変の分子生物学的解析

・血管腫・血管奇形症例標本のトランスクリプトーム 解析

- 血管形成機構の基礎研究 主に血管内皮細胞に焦点 を当てた血管腔形成の分子メカニズム研究を行う.

・血管腫・血管奇形患者の候補遺伝子ゲノム解析

\section{おわりに}

近年岡山大学病院には中国四国地方はもとより, 全 国から血管腫・血管奇形の患者が診療に訪れている。
放射線科が空口になることもあるが，形成外科・整形 外科・皮膚科・耳鼻科 - 眼科 - 口腔外科 - 心臓血管外 科・循環器内科など, 多くの科から紹介を受けている. 血管腫・血管奇形に対する我々放射線科の専門分野は IVR・画像診断であるが, IVRの役割が大きくなるに 伴って, IVR 単独では治療できない患者の受診も増加 している. 2009年12月より院内で形成外科・放射線科 合同の症例検討カンファレンスを始めている。さらに 多くの科と十分連携して診療に当たっていきたいと考 えている.

\section{文献}

1) Enjolras $O$ : Classification and management of the various superficial vascular anomalies : Hemangiomas and vascular malformations. J Dermatol (1997) 24, 701-710.

2) Kohout MP, Hansen M, Pribaz JJ, Mulliken JB : Arteriovenous malformations of the head and neck: natural history and management. Plast Reconstr Surg (1998) 102, 643-654.

3 ) Hyodoh H, Hori M, Akiba H, Tamakawa M, Hyodoh K, Hareyama M:Peripheral vascular malformations: imaging, treatment, approaches, and therapeutic issues. Radiographics (2005) 25, S159-171.

4) Cabrera J, Cabrera J Jr, Garcia-Olmedo MA, Redondo $\mathrm{P}$ : Treatment of venous malformations with sclerosant in microfoam form. Arch Dermatol (2003) 139, 1409-1416.

5 ) Mimura H, Fujiwara H, Hiraki T, Gobara H, Mukai T, Hyodo T, Iguchi T, Yasui K, Kimata Y, Kanazawa S : Polidocanol sclerotherapy for painful venous malformations : evaluation of safety and efficacy in pain relief. Eur Radiol (2009) 10, 2474-2480.

$6)$ Cho SK, Do YS, Shin SW, Kim DI, Kim YW, Park KB, Kim EJ, Ahn HJ, Choo SW, Choo IW : Arteriovenous malformations of the body and extremities : analysis of therapeutic outcomes and approaches according to a modified angiographic classification. J Endovasc Ther (2006) 13, 527-538. 